\title{
Performance of Vegetable Production and Marketing in Peri-Urban Kumasi, Ghana
}

\author{
Jusufu Abdulai ${ }^{1}$, Fred Nimoh ${ }^{2}$, Samuel Darko-Koomson ${ }^{2} \&$ Kassoh Fallah Samuel Kassoh ${ }^{1}$ \\ ${ }^{1}$ Sierra Leone Agricultural Research Institute (SLARI), Tower Hill Freetown, Sierra Leone \\ ${ }^{2}$ Department of Agricultural Economics, Agribusiness and Extension, Kwame Nkrumah University of Science \\ and Technology, Kumasi, Ghana \\ Correspondence: Samuel Darko-Koomson, Department of Agricultural Economics, Agribusiness and Extension \\ Kwame Nkrumah University of Science and Technology, Kumasi, Ghana. E-mail: sdarkoomson@hotmail.com
}

Received: November 9, 2016

Accepted: January 19, 2017

Online Published: February 15, 2017

doi:10.5539/jas.v9n3p202

URL: http://dx.doi.org/10.5539/jas.v9n3p202

The research was financed by the West African Agricultural Productivity Programme in Sierra Leone (WAAPP/SL) through the Sierra Leone Agricultural Research Institute (SLARI).

\begin{abstract}
Vegetable production and marketing play an important role in providing income and employment for a significant proportion of small holder farmers and traders in Ghana. Yet, farmers are dissatisfied, claiming that they earn less marketing margins than is due them as compared to traders in the value chain. Due to lack of a holistic assessment of actors' performance, this assertion remains unjustifiable. It is against this backdrop that this study investigates the performance of farmers, wholesalers and retailers along the investment channels of three major leafy vegetables (spring onions, lettuce and cabbage) in peri-urban Kumasi. Using a two-stage sampling technique, a total of 217 actors comprising 147 farmers, 30 wholesalers and 40 retailers, were sampled. Marketing margin analysis and returns on investments (ROIs) were used to assess the performance of actors' investments. Results show that vegetable production is dominated by males (91 percent) and trading by females (83 percent of wholesalers and 100 percent of retailers) respectively. Wholesalers recorded the highest yearly marketing margins for spring onions and cabbage (GHф 3369 and GH $\varnothing 17$ 376) (1US\$ = GH $\varnothing$ 3.6), while farmers obtained the highest yearly margins (GHф 3 630) for lettuce. Farmers obtained the most ROIs of 28, 145 and 79 percents for spring onions, lettuce and cabbage respectively. Based on accrued ROIs, the study concludes that farmers are more efficient in the investments in these vegetables than traders. Information flow gap was found to be a major cause of farmers' scepticism on margin distribution because 76 percent of farmers had no information on market prices of products. It is recommended that an efficient policy on market price information system for vegetables be implemented via convenient means such as farmer associations and weekly radio broadcasts of product prices to all actors.
\end{abstract}

Keywords: marketing margins, performance, returns on investments, vegetable investment

\section{Introduction}

Vegetable production and marketing, amongst other peri-urban agricultural activities, continue to play a significant role in the supply of urban foods. Their importance cannot be overemphasized because of the creation of employment opportunities, which acts as a unique source of livelihood especially for the urban poor thereby reducing urban poverty. Vegetable production activities in and around urban centres also has the potential of contributing to the attainment of the first two priorities of the seventeen major sustainable development goals (SDGs 1\&2) of the United Nations - reduction of extreme poverty and hunger. Without the achievement of these goals by 2030, the impossibility of achieving the full range of the sustainable development goals also increases (FAO, 2015). An indication of such functions can be seen in the increasing number of actors at both the production level and along the marketing channels of vegetables in different countries in the world. Some of the major actors that are involved in peri-urban vegetable production and marketing include producers, and market intermediaries like wholesalers, retailers, commission agents and brokers. 
According to Food Outlook (2012), vegetable production occupies an area of $1.1 \%$ of the world's agricultural land, exceeding fruits production by $0.1 \%$. Moreover, the sector's outputs in recent times exceeds that of cereals on a worldwide paradigm, with cultivated land area doubling cereals between 1960 and 2000 (Amoah, Debrah, \& Razak, 2014). On a worldwide basis, the United Nations Development Program (UNDP) has further estimated that about 800 million people are actively engaged in peri-urban agricultural activities, and about 200 million are considered to be market producers (UNDP, 1996). Consequently, such huge gliding of active labour force in peri-urban vegetable production activities will in no doubt be observed to concurrently have significant impact on the yields of such products. In 2007, a total of 880 million tonnes of vegetables were said to have been produced globally and was speculated to reach 1.2 billion tonnes by 2015 (FAO, 2006). The overwhelming expansion of this sector in peri-urban areas is mainly due to its fast income deriving potentials, compared to a number of other agricultural products cultivated on annual or biennial bases. For instance, it has been estimated that horticultural producers derive per capital farm income five times more than cereal farmers (Lumpkin, Weinberger, \& Moore, 2005).

As in many other sub-Sahara African countries, majority of urban dwellers in Ghana still remain poor. This group lives in sub-standard areas especially slums, have less access to protein and other nutritious food and face huge economic hardship (Hoornweg \& Munro-Faure, 2008). They are normally referred to as the urban poor who have sought alternative remedial measures to the improvement of their economic wellbeing through the adoption and embarking on intensive sustainable peri-urban agricultural activities. Vegetable production and marketing are mostly undertaken in large scale since the capital requirement is lower and more affordable compared to livestock and poultry. Such activities of peri-urban agriculture have in recent times assisted in improving livelihood earnings of farmers and has further empowered them in meeting other non-food household commitments such as paying of school fees for their children, meeting costs of medication and house rents. Moreover, the economy has also benefited from revenue generated from the production and marketing of vegetables in Ghana. For instance, Ghana generated revenue of US\$ 11.5 million and US\$ 75.64 million from exportation of organic fruits and vegetables respectively within 1995 to 2006 (V. Owusu \& A. M. Owusu, 2010).

The production of vegetables is generally labour demanding in nature. In Ghana, the labour demand increases during the dry season when farmers are faced with low or very erratic rainfall and in scenarios of severe drought. The execution of the various farm management practices ranging from farm clearing, ploughing of land, bed construction, ridging, harrowing of large soil crumbs and even weeding of the farm land become very cumbersome for farmers due to hard and compacted nature of the soil. Moreover, fetching of water for field irrigation poses further constraints since most of the shallow wells, mainstreams, and waste water drains usually dry up during this time. This causes farmers to incur more cost on fuel purchase or on labour for conveyance of irrigation water for farm irrigation purposes along considerable distances (Obuobie et al., 2006).

Vegetable outputs from peri-urban farming activities are usually distributed throughout the country by middlemen, especially wholesalers and retailers, who visit farms and buy cultivated products that are ready for the market (ibid.). Farmers' marketing of vegetable products is highly concentrated at farm gates. This is because there are barriers, created by cartels, which have been formed by market intermediaries in existing markets and mainly managed by the market queen (locally known as 'Ohemma') (Ortiz, Campbell, \& Hyman, 2010). The formation of cartels by market intermediaries were purposely for price and quantity regulatory measures aimed at maintaining product price stability and prevention of product gluts in the markets (Ortiz et al., 2010). If not done, product gluts in the markets were speculated of having the potential of subjecting their operations to loss, thinking about the vulnerable and perishable nature of vegetable products in general (ibid.). Such product perishability is worsened by lack of appropriate preservation facilities that can help prolong product shelf life.

Furthermore, prices offered for vegetable products at farm gates are to a large extent determined by traders because of their knowledge on existing market conditions and further empowered by the price collusion mechanism and cartel power. Such activities in the vegetable marketing system have in recent times resulted in alarming claims by farmers that they are being cheated in the marketing margins by traders, despite the laborious nature of their production activities. Though being anecdotal and uncorroborated, such a scenario will however be very debilitating, thinking about the concerted stride being made by all agricultural sectors in the attainment of food security in the country of which the vegetable sector is playing a unique part. This therefore calls for an empirical investigation that can unravel and holistically present evidence of the overall status of performance along the vegetable marketing channels in the country. Related literature such as Drechsel and Keraita (2014) that looked at marketing channels of exotic vegetables in peri-urban Kumasi, Ghana, overlooked the aspect of performance assessment of actors' investments in terms of distribution of marketing margins, and the quantification of margins for the various participants along product channels. Moreover, a performance study by 
Haruna, Nkegbe, and Ustarz (2012), in a remote town of Pwalugu in the Upper East Region of Ghana, was mainly on tomatoes. Thus, not a study in a peri-urban setting like Kumasi metropolis and not on leafy vegetables like spring onions, lettuce and cabbage, found to play unique nutrient supplementation function for average urban dwellers in Ghana, especially those that have large proportions of daily dietary intake from restaurants and street food vendors, exists.

This study is therefore imperative and contributes profoundly to knowledge by carefully assessing the performance status of actors in the investment of these three leafy vegetables that are predominantly produced and marketed in peri-urban Kumasi, Ghana. Hence, informing decision makers on pragmatic policies that can help improve performance and overall wellbeing of key actors as well as consumers of these products.

\section{Material and Methods}

\subsection{Material Studied}

This paper studied three major leafy vegetables; spring onions, lettuce and cabbage in peri-urban Kumasi, Ghana. It critically looks at the performance of three key actors; farmers, wholesalers and retailers in the investment in these three leafy vegetables in Ghana, taking Kumasi metropolis as a case study.

\subsection{Description of Study Area}

The study was carried out in Kumasi metropolis, Ghana's second largest city and the capital of the Ashanti Region. Kumasi Metropolis has an approximate area of 254 square kilometres and is located between latitudes $6^{\circ} 35^{\prime}$ and $6^{\circ} 4^{\prime} \mathrm{N}$ and longitudes $1^{\circ} 30^{\prime}$ and $1^{\circ} 35^{\prime} \mathrm{E}$. It is the most populous district in the Ashanti Region, with a population of 2,035,064 (GSS, 2012) and an annual growth rate of 4.8\%. The climate of Kumasi Metropolis falls within the sub-equatorial type and has an average temperature ranging from $21.50{ }^{\circ} \mathrm{C}$ to $30.70{ }^{\circ} \mathrm{C}$ and average annual rainfall of about $625 \mathrm{~mm}$. Kumasi's peri-urban area has a radius of approximately $40 \mathrm{~km}$ from the city centre (Blake \& Kasanga, 1997). In urban Kumasi, most lands under vegetable cultivation are owned by government institutions and private developers. Vegetable production covers an area of about 41 ha in the urban area while the peri-urban area has more than 12,000 hectares under irrigated vegetable production (Cornish \& Laurence, 2001). It was estimated that about 12,000 smallholder farmers were involved in vegetable farming during the dry season in both urban and peri-urban Kumasi (Cornish, Aidoo, \& Ayamba, 2001). Kumasi metropolis was deemed suitable for the study due to its predominant peri-urban vegetable farming activities and its function as one of the major hubs for the supply of vegetables, especially leafy vegetables like spring onions, lettuce and cabbage, to most of the other major cities in the country.

\subsection{Research Methodology}

\subsubsection{Sampling Method}

A two-stage sampling technique was adopted for the study. Firstly, purposive sampling was used to select all producing areas identified during the reconnaissance survey. This was followed by a simple random sampling procedure to select $75 \%$ of all farmers registered from each of the producing areas making a total of 147 farmers. The rationale for $75 \%$ of farmers from each of the producing areas was to have a fair representation from each of these producing sites. Two categories of traders were considered for this investigation especially resident wholesalers and retailers since they are the major agents in the marketing activities of vegetables in peri-urban Kumasi. Also, being that they are numerous and more easily accessible compared to brokers and commission agents who are more sparse and difficult to be located. In the sampling of traders, the Abinchie market was purposively selected because of its incorporated trading activities of all vegetables in large quantities especially leafy vegetables like lettuce, cabbage and spring onions. A comprehensive traders' list was absent when requested from the market secretary during the data collection exercise. However, traders present were categorised into wholesalers and retailers, followed by randomly selecting thirty (30) wholesalers and forty (40) retailers for the retrospective data enumeration process on the targeted vegetables. In total, a sample size of 217 actors was considered for the study. Primary data was mainly used which was collected through a pre-tested semi-structured questionnaire. Table 1 shows the number of farmers sampled from each of the producing sites. 
Table 1. Estimated population and number of farmers sampled from each producing site

\begin{tabular}{lll}
\hline Vegetable producing area & Population & $\mathbf{7 5 \%}$ sampled \\
\hline TCC & 16 & 12 \\
GYINYASE & 30 & 23 \\
POKUSIKA & 44 & 33 \\
KENTIKRONO & 34 & 25 \\
APPIADU & 15 & 11 \\
EMENA & 32 & 24 \\
APPEMSO & 25 & 19 \\
TOTAL & $\mathbf{1 9 6}$ & $\mathbf{1 4 7}$ \\
\hline
\end{tabular}

Source: Field survey, 2015.

\subsubsection{Data Analysis Techniques}

Data was analysed using SPSS v21 software. Means, standard deviations, frequencies and percentages were used for the analysis of actors' socio-economic characteristics. Marketing margins and returns on investments (ROI) analysis were used for the assessment of performance of the marketing systems of the various actors considered for the study. According to Adugna (2009), performance is said to be best assessed using marketing margin analysis of actors' investment activities. Moreover, the study took into consideration the assumption of Kohls and Uhl (1985) which states that marketing margin is the difference between what consumers pay and the farm gate price per unit of the product, and also assuming that products move from producers, wholesalers and retailers in that order. The marketing margins for each of the vegetables for the various actors were computed using the formula below (Mou, 2012; Bakari \& Usman, 2013),

$$
\begin{gathered}
M M F_{i}=T S F_{i}-T P C F_{i} \\
M M T_{i}=T S T_{i}-P C T_{i} \\
P M F_{i}=T S F_{i}-T P C F_{i}-T M C F_{i} \\
P M T_{i}=T S T_{i}-P C T_{i}-T M C T_{i}
\end{gathered}
$$

Where, $M M F_{i}$ is the marketing margin for farmer $i, T S F_{i}$ is the total sales of farmer $i, T P C F_{i}$ is the total production cost of farmer $i, M M T_{i}$ is the marketing margin for trader $i, T S T_{i}$ is the total sales of trader $i, P C T_{i}$ is the purchasing cost of trader $i, P M F_{i}$ is the profit margin of farmer $i, T M C F_{i}$ is the total marketing cost of farmer $i, P M T_{i}$ is the profit margin of trader $i$ and $T M C T_{i}$ is the total marketing cost of trader $i$.

An analysis of returns on investment for the operations of the targeted actors was aimed at understanding the efficiency of operations of the various actors in the marketing of the targeted vegetables in the metropolis. Hence, the returns on investment for the various actors were computed by dividing the profit obtained by the total cost incurred in the transaction process expressed as a percentage. Mathematically given as,

\section{Results and Discussion}

$$
R O I=\frac{\text { Actors'yearly profit (per vegetable) }}{\text { Actors'yearly total cost incurred (per vegetable) }} \times 100 \%
$$

\subsection{Socio-Economic Characteristics of Actors}

According to Randela (2005), the analysis of demographic features are important for any economic data as they play a unique role in the actor's decision making and hence need to be understood. Table 2 gives the socio-economic characteristics of actors in Kumasi metropolis. 
Table 2. Demographic characteristic of respondents in Kumasi metropolis

\begin{tabular}{|c|c|c|c|}
\hline Socio-economic variables & Farmers & Wholesalers & Retailers \\
\hline Variables & $\mathbf{N}(\%)$ & $\mathbf{N}(\%)$ & $\mathbf{N}(\%)$ \\
\hline \multicolumn{4}{|l|}{ Categorical variables } \\
\hline \multicolumn{4}{|l|}{ Sex/Gender } \\
\hline Male & 133(90.50) & $5(16.70)$ & $0(0.00)$ \\
\hline Female & $14(9.50)$ & $25(83.30)$ & $40(100)$ \\
\hline \multicolumn{4}{|l|}{ Marital status } \\
\hline Married & $115(78.20)$ & $22(73.30)$ & $24(60.00)$ \\
\hline Single & $26(17.70)$ & $2(6.70)$ & $10(25.00)$ \\
\hline Divorced & $2(1.40)$ & $5(16.70)$ & $4(10.00)$ \\
\hline Widowed & $4(2.70)$ & $1(3.30)$ & $2(5.00)$ \\
\hline \multicolumn{4}{|l|}{ Educational level } \\
\hline None & $36(24.50)$ & $8(26.70)$ & $13(32.50)$ \\
\hline Primary & $41(27.90)$ & $6(20.00)$ & $7(17.50)$ \\
\hline Junior secondary & $55(37.40)$ & $12(40.00)$ & $15(37.50)$ \\
\hline Senior secondary & $9(6.10)$ & $4(13.30)$ & $5(12.50)$ \\
\hline Tertiary & $6(4.10)$ & $0(0.00)$ & $0(0.00)$ \\
\hline \multicolumn{4}{|l|}{ Ethnicity } \\
\hline Akan & $73(49.70)$ & $26(86.70)$ & $30(75.00)$ \\
\hline Ewe & $1(0.70)$ & $0(0.00)$ & $0(0.00)$ \\
\hline Northern & $72(48.90)$ & $4(13.30)$ & $8(20.00)$ \\
\hline Others & $1(0.70)$ & $0(0.00)$ & $2(5.00)$ \\
\hline \multicolumn{4}{|l|}{ Religion } \\
\hline Christianity & $109(74.10)$ & $28(93.30)$ & $29(72.50)$ \\
\hline Islam & $37(25.20)$ & $2(6.70)$ & $11(27.50)$ \\
\hline Traditional & $1(0.70)$ & $0(0.00)$ & $0(0.00)$ \\
\hline \multicolumn{4}{|l|}{ Access to market information } \\
\hline Yes & $36(24.50)$ & - & - \\
\hline No & $111(75.50)$ & - & - \\
\hline Continuous Variables & $M(S D)$ & $M(S D)$ & $M(S D)$ \\
\hline Age & $38.89(10.46)$ & $41.87(7.89)$ & $38.45(8.30)$ \\
\hline Family size & $5.22(2.43)$ & $6.27(1.95)$ & $5.23(3.39)$ \\
\hline Years of formal Education & $7.86(3.57)$ & $8.36(2.36)$ & $8.48(3.50)$ \\
\hline
\end{tabular}

Note. $M=$ mean; $(S D)=$ standard deviation, $\mathrm{N}=$ Frequency of respondents and $(\%)=$ percentage of respondents.

Source: Field survey, 2015.

The results from Table 2 show that vegetable farming is dominated by males (91\%) while marketing is dominated by females ( $83 \%$ of wholesalers and $100 \%$ of retailers). This finding concurs to that of Obuobie, Danso, and Drechsel (2003) who indicated that in most of the West African cities, vegetable trading is mainly dominated by women either due to cultural or traditional beliefs. An earlier report by Maxwell in 1999 indicated that urban retail marketing and petty trade are sub-sectors which have long been dominated by women in West Africa. Conversely, Baba et al. (2010) found that, in Jammu and Kashmir, India, male participation in vegetable cultivation was more important than females. A majority of farmers $(78 \%)$, wholesalers $(73 \%)$ and retailers $(60 \%)$ were observed to be married. Most of the farmers (37\%) had only attained Junior High School level of education with average number of years of formal education being 8 years. Invariably, majority of wholesalers $(40 \%)$ and retailers $(38 \%)$ had also only attained Junior high school level of education with 8 and 9 years of schooling on the average respectively. Basically, a majority of both farmers $(50 \%)$ and traders $(87 \%$ wholesalers and $75 \%$ retailers) are from the Akan ethnic group with $74 \%$ of farmers, $93 \%$ of wholesalers and $73 \%$ of retailers being Christians respectively. On the average, the ages of farmers, wholesalers and retailers were estimated at 39,42 and 39 years with average family sizes of 5, 6 and 5 persons per household respectively. Most farmers 
(76\%) interviewed do not have access to information on the prices of vegetables traded in markets located in both the metropolis and other cities in the country.

\subsection{Performance Assessment of Actors in Spring Onion Investment in Peri-Urban Kumasi}

3.2.1 Production and Marketing Costs Analysis of Spring Onions for Farmers per Year

The results in Table 3 show the various production and marketing costs incurred by farmers per year.

Table 3. Production and marketing costs analysis of spring onions for farmers per year

\begin{tabular}{|c|c|c|c|}
\hline Item & $M(S D)$ & Min & Max \\
\hline Land preparation $\mathrm{GH} \phi$ & $219.97(92.54)$ & 66.12 & 522.00 \\
\hline Sowing GHф & $199.09(53.52)$ & 118.30 & 334.08 \\
\hline Weeding GH $\varnothing$ & $122.93(60.18)$ & 17.40 & 208.80 \\
\hline Fertilizer application $\mathrm{GH} \varnothing$ & $89.32(36.51)$ & 60.90 & 130.50 \\
\hline Manure application $\mathrm{GH} \varnothing$ & $154.11(31.95)$ & 113.10 & 261.00 \\
\hline Cost of seedling GH $\varnothing$ & 382.98(201.97) & 174.00 & 1044.00 \\
\hline Cost of manure $\mathrm{GH} \phi$ & $194.73(41.75)$ & 121.80 & 365.40 \\
\hline Cost of Attack GHф & $132.45(26.75)$ & 26.10 & 174.00 \\
\hline Cost of Golan GH $\varnothing$ & $145.41(23.25)$ & 104.40 & 174.00 \\
\hline Cost of Consider GH $\varnothing$ & $137.39(20.84)$ & 78.30 & 156.60 \\
\hline Cost of Dytrin GHф & $151.25(19.30)$ & 121.80 & 174.00 \\
\hline Cost of Cobos GHф & $143.55(8.70)$ & 139.20 & 156.60 \\
\hline Cost of Emma GHф & $136.30(18.11)$ & 121.80 & 156.60 \\
\hline Cost of Melton GHф & $128.13(22.04)$ & 69.60 & 156.60 \\
\hline Depreciated fixed cost $\mathrm{GH} \phi$ & $19.48(19.08)$ & 1.44 & 91.00 \\
\hline Average total production costs GHc & 2357.09 & & \\
\hline \multicolumn{4}{|l|}{ Marketing costs $G H \phi$} \\
\hline Searching costs & $20.99(16.02)$ & 1.74 & 87.00 \\
\hline Communication costs & $4.01(3.56)$ & 0.21 & 20.88 \\
\hline Negotiation costs & $4.86(3.15)$ & 0.87 & 13.92 \\
\hline Average total marketing costs GHe & 29.86 & & \\
\hline Total costs GHC & 2386.95 & & \\
\hline \multicolumn{4}{|l|}{ Revenue analysis } \\
\hline Number of $40 \mathrm{~kg}$ bags traded & $55.58(41.02)$ & 8.70 & 208.80 \\
\hline Total kg sold & $2222.98(1640.69)$ & 348.00 & 8352.00 \\
\hline Cost per $40 \mathrm{~kg}$ bag & $55.63(12.56)$ & 35.00 & 100.00 \\
\hline Revenue per year GHc & 3056.44 & & \\
\hline Marketing margin GHC & 699.35 & & \\
\hline Profit margin GHe & 669.49 & & \\
\hline Margin per 40 kg bag GHc & 12.58 & & \\
\hline Margin per kilo onion GHe & 0.32 & & \\
\hline
\end{tabular}

Note. $M=$ mean; $(S D)=$ standard deviation, Min = minimum, Max = maximum.

1 US Dollar $(\$)=3.6$ Ghana New Cedi $(\mathrm{GH} \phi)$ in 2015. Two (2) freshly harvested beds of Onion $=40 \mathrm{~kg}$ on average.

Source: Author's computation from survey data, 2015.

The average annual production cost was estimated at GHф 2,357 with an average marketing cost of GHф 30 . About 56 bags of spring onions each weighing $40 \mathrm{~kg}$ which was estimated to equal the weight of a freshly harvested bed of spring onions in the metropolis was sold by farmers yielding revenue of GH $\varnothing 3,056$ per year. Marketing and profit margins were estimated at GHф 699 and $\mathrm{GH} \notin 670$ respectively, with yearly per kilo marketing margins of $\mathrm{GH} \phi 0.32$. 
3.2.2 Purchasing and Marketing Costs Analysis of Spring Onions for Traders per Year

Table 4 displays the transaction activities of traders.

Table 4. Purchasing and marketing costs analysis of spring onions for traders per year

\begin{tabular}{|c|c|c|c|}
\hline Item & $M(S D)$ & Min & Max \\
\hline \multicolumn{4}{|l|}{ Wholesalers } \\
\hline Purchase trip per year & $96.00(0.00)$ & 96.00 & 96.00 \\
\hline Number of $40 \mathrm{~kg}$ bags & $345.60(92.74)$ & 192.00 & 480.00 \\
\hline Equivalent kg per year & 13824.00(3709.79) & 7680.00 & 19200.00 \\
\hline Unit cost per bag & $57.60(4.81)$ & 50.00 & 65.00 \\
\hline Unit sales per bag & $67.40(4.01)$ & 62.00 & 74.00 \\
\hline Revenue per year GHc & 23452.80 & & \\
\hline Purchasing cost GHe & 20083.20 & & \\
\hline \multicolumn{4}{|l|}{ Marketing costs $G H \phi$} \\
\hline Load and unloading & $422.40(170.53)$ & 288.00 & 768.00 \\
\hline Transportation & $681.60(348.19)$ & 384.00 & 1440.00 \\
\hline Market toll & $74.18(25.07)$ & 48.00 & 96.00 \\
\hline Negotiation & $112.00(69.43)$ & 4.80 & 200.00 \\
\hline Communication & $134.29(66.42)$ & 19.20 & 250.00 \\
\hline Others & $96.00(0.00)$ & 96.00 & 96.00 \\
\hline Total marketing costs GHC & 1520.47 & & \\
\hline Total costs GHe & 21603.67 & & \\
\hline Marketing margin GHc & 3368.80 & & \\
\hline Profit margin GHc & 1848.33 & & \\
\hline Margin per $40 \mathrm{~kg}$ bag GHc & 9.75 & & \\
\hline Margin per kilo onions GHe & 0.24 & & \\
\hline \multicolumn{4}{|l|}{ Retailers } \\
\hline Purchase trip per year & $96.00(0.00)$ & 96.00 & 96.00 \\
\hline Number of $40 \mathrm{~kg}$ bags & $144.00(43.56)$ & 96.00 & 192.00 \\
\hline Equivalent kg per year & $5760.00(1742.37)$ & 3840.00 & 7680.00 \\
\hline Unit cost per bag & $64.72(4.31)$ & 56.00 & 70.00 \\
\hline Unit sales per bag & $74.89(4.35)$ & 67.00 & 82.00 \\
\hline Revenue per year GHc & 10794.67 & & \\
\hline Purchasing cost GHe & 9376.00 & & \\
\hline \multicolumn{4}{|l|}{ Marketing costs $G H \phi$} \\
\hline Load and unloading & $118.67(61.31)$ & 48.00 & 216.00 \\
\hline Transportation & $236.00(112.95)$ & 96.00 & 432.00 \\
\hline Market toll & $87.53(18.86)$ & 48.00 & 96.00 \\
\hline Negotiation & $76.62(38.23)$ & 4.80 & 144.00 \\
\hline Communication & $128.85(58.61)$ & 48.00 & 192.00 \\
\hline Others & $80.00(27.71)$ & 48.00 & 96.00 \\
\hline Total marketing costs GHe & 727.66 & & \\
\hline Total costs GHe & 10103.66 & & \\
\hline Marketing margin GHc & 1418.67 & & \\
\hline Profit margin GHc & 691 & & \\
\hline Margin per $40 \mathrm{~kg}$ bag GHC & 9.85 & & \\
\hline Margin per kilo onion GHc & 0.25 & & \\
\hline
\end{tabular}

Note. $M=$ mean; $(S D)=$ standard deviation, Min = minimum, Max $=$ maximum.

1 US Dollar $(\$)=3.6$ Ghana New Cedi $(\mathrm{GH} \phi)$ in 2015. Two (2) freshly harvested beds of Onion $=40 \mathrm{~kg}$ on average.

Source: Authors computation from survey data, 2015. 
It can be observed that the average revenue obtained by wholesalers for the sale of 346 bags of spring onions each weighing $40 \mathrm{~kg}$ was $\mathrm{GH} \phi 23,453$ per year. Marketing and profit margins were estimated at $\mathrm{GH} \phi 3,369$ and GH $\notin 1,848$ while per kilo marketing margins was estimated at GH $\not 0.24$ per year. Retailers' yearly accrued revenue from the sale of 144 bags of spring onions was GHф 10,795 yielding marketing margins of GH $\varnothing 1,419$. Estimated profit margins and margins per kilo of spring onions were GHф 691 and $\mathrm{GH} \varnothing 0.25$ per year respectively.

\subsubsection{Summary of Actors' Performance in Spring Onion Investment in Peri-Urban Kumasi}

Table 5 gives a comprehensive summary for the analysis of marketing margin distribution amongst actors that are involved in the trade of spring onions for the sample used.

Table 5. Summary of spring onion marketing margin distribution amongst actors per year

\begin{tabular}{llll}
\hline Item & Producers & Wholesalers & Retailers \\
\hline Purchase prices GH $\phi$ & - & 20083.20 & 9376.00 \\
Production cost GH $\phi$ & 2357.09 & - & - \\
Marketing costs GHф & & & \\
Loading and unloading & - & 422.40 & 118.67 \\
Transportation & - & 681.60 & 236.00 \\
Market toll & - & 74.18 & 87.53 \\
Negotiation costs & 4.86 & 112.00 & 76.62 \\
Communication costs & 4.01 & 134.29 & 128.85 \\
Search costs & 20.99 & - & - \\
Other marketing cost & - & 96.00 & 80.00 \\
Total marketing costs GH $\varnothing$ & $\mathbf{2 9 . 8 7}$ & $\mathbf{1 5 2 0 . 4 7}$ & $\mathbf{7 2 7 . 6 6}$ \\
Total costs GH $\varnothing$ & 2386.96 & 21603.67 & 10103.65 \\
Sales GH $\phi$ & 3056.44 & 23452.80 & 10794.67 \\
Marketing margin GH $\phi$ & $\mathbf{6 9 9 . 3 5}$ & $\mathbf{3 3 6 8 . 8 0}$ & $\mathbf{1 4 1 8 . 6 7}$ \\
Percentage share of margin & $\mathbf{1 2 . 7 4}$ & $\mathbf{6 1 . 4 0}$ & $\mathbf{2 5 . 8 6}$ \\
Profit margin GH $\phi$ & 669.49 & 1848.33 & 691.00 \\
Percentage share of profit & $\mathbf{2 0 . 8 6}$ & $\mathbf{5 7 . 6 0}$ & $\mathbf{2 1 . 5 4}$ \\
Total kg traded & 2222.98 & 13824.00 & 5760.00 \\
Number of 40 kg bags & 55.57 & 345.60 & 144.00 \\
Margins/40 kg bag & 12.58 & 9.75 & 9.85 \\
Margin/kilo GH $\varnothing$ & 0.31 & 0.24 & 0.25 \\
Percentage margin/kilo & $\mathbf{3 8 . 8 6}$ & $\mathbf{3 0 . 2}$ & $\mathbf{3 0 . 9 4}$ \\
Returns on invest (\%) & $\mathbf{2 8 . 0 0}$ & $\mathbf{8 . 6 0}$ & $\mathbf{6 . 8 0}$ \\
\hline
\end{tabular}

Note. $M=$ mean; $(S D)=$ standard deviation, Min $=$ minimum, Max $=$ maximum.

1 US Dollar $(\$)=3.6$ Ghana New Cedi $(\mathrm{GH} \phi)$ in 2015. Two (2) freshly harvested beds of Onion $=40 \mathrm{~kg}$ on average.

Source: Author's computation from survey data, 2015.

The results show that the marketing margins obtained by farmers, wholesalers and retailers were GH $\phi 699(13 \%)$, GH $\notin 3,369(61 \%)$ and GH $\not 1,419(26 \%)$ respectively. This indicates that traders had more marketing margins compared to farmers in the marketing of spring onions. The results are in consonance with the findings of Woldesenbet (2013) in the Woredas of Habro and Kobolcha in Oromia region, Ethiopia, who also discovered similar marketing margin distribution amongst actors involved in the marketing of vegetable products. However, further analysis on the distribution of marketing margins amongst actors revealed that, irrespective of the high marketing margins acquired by traders, farmers' margins per kilo of spring onions traded exceed those of traders. The results show that while farmers received $\mathrm{GH} \phi 0.31$ (39\%), wholesalers and retailers received $\mathrm{GH} \phi 0.24$ $(30 \%)$ and $\mathrm{GH} \phi 0.25(31 \%)$ respectively. Farmers are therefore better-off in terms of per kilo marketing margin distribution compared to traders. This can be reiterated based on the returns on investment analysis which shows that for every one cedi invested in spring onions by farmers, they earned returns of $28 \%$, while wholesalers and retailers earned $9 \%$ and $7 \%$ respectively. This result conforms to the finding of Haruna et al. (2012), who also 
discovered that tomato farmers in Pwalugu village in the Upper East region of Ghana had more returns on capital employed compared to their counterpart traders.

\subsection{Performance Assessment of Actors in Lettuce Investment in Peri-Urban Kumasi}

3.3.1 Production and Marketing Costs Analysis of Lettuce for Farmers per Year

Table 6 provides the production costs and attributed marketing costs incurred by farmers in the production and marketing of lettuce in Kumasi metropolis.

Table 6. Production and marketing costs analysis of lettuce for farmers per year

\begin{tabular}{|c|c|c|c|}
\hline Item & $M(S D)$ & Min & Max \\
\hline Land preparation $\mathrm{GH} \varnothing$ & $300.96(160.11)$ & 65.70 & 788.40 \\
\hline Sowing $\mathrm{GH} \varnothing$ & $189.94(147.41)$ & 13.14 & 840.96 \\
\hline Weeding GH $\varnothing$ & 285.61(109.98) & 68.33 & 504.58 \\
\hline Fertilizer application $\mathrm{GH} \varnothing$ & $103.15(37.56)$ & 73.58 & 189.22 \\
\hline Manure application GHф & $127.02(69.74)$ & 52.56 & 315.36 \\
\hline Cost of seed GHф & $252.47(151.07)$ & 102.49 & 788.40 \\
\hline Cost of manure GHф & $230.27(253.94)$ & 26.28 & 1576.80 \\
\hline Cost of Attack GHф & $108.60(62.20)$ & 19.71 & 315.36 \\
\hline Cost of Golan GHф & $83.22(42.10)$ & 26.28 & 131.40 \\
\hline Cost of Consider GH $\not$ & $108.05(70.12)$ & 26.10 & 313.20 \\
\hline Cost of Dytrin GHф & $147.63(73.12)$ & 39.42 & 315.36 \\
\hline Cost of Cobos GHф & $144.54(35.58)$ & 118.26 & 197.10 \\
\hline Cost of Emma GHф & $189.22(178.41)$ & 63.07 & 315.36 \\
\hline Cost of Melton GHф & $109.69(64.87)$ & 36.79 & 262.80 \\
\hline Depreciated fixed cost $\mathrm{GH} \varnothing$ & $56.07(54.93)$ & 4.13 & 261.91 \\
\hline Average total production costs GHe & 2436.45 & & \\
\hline \multicolumn{4}{|l|}{ Marketing costs $G H \phi$} \\
\hline Searching costs & $31.71(24.20)$ & 2.63 & 131.40 \\
\hline Communication costs & $6.06(5.38)$ & 0.32 & 31.54 \\
\hline Negotiation costs & $7.35(4.73)$ & 1.31 & 21.02 \\
\hline Average total marketing costs $\mathbf{G H}$ & 45.11 & & \\
\hline Total costs GHe & 2481.56 & & \\
\hline \multicolumn{4}{|l|}{ Revenue analysis } \\
\hline Number of $15 \mathrm{~kg}$ bags produced & $113.49(81.76)$ & 2.63 & 525.60 \\
\hline Total kg sold & $1702.39(1226.38)$ & 39.42 & 7884.00 \\
\hline Cost per $15 \mathrm{~kg}$ bag GH $\varnothing$ & $51.32(12.91)$ & 10.00 & 120.00 \\
\hline Revenue per year GHe & 6066.26 & & \\
\hline Marketing margin GHc & 3629.82 & & \\
\hline Profit margin GHc & 3584.70 & & \\
\hline Margin per bag GHe & 31.98 & & \\
\hline Margin per kilo GHe & 2.13 & & \\
\hline
\end{tabular}

Note. $M=$ mean $(S D)=$ standard deviation, Min $=$ minimum, Max $=$ maximum.

1 US Dollar $(\$)=3.6$ Ghana New Cedi $(\mathrm{GH} \phi)$ in 2015 , Two (2) freshly harvested beds of lettuce $=15 \mathrm{~kg}$ on average.

Source: Author's computation from survey data, 2015.

The marketing margin per kilo of lettuce traded by farmers per year was found to be GH $\varnothing 2.13$. A total production cost of $\mathrm{GH} \notin 2,437$ was incurred for the production of 114 bags of lettuce each weighing $15 \mathrm{~kg}$. This was estimated as an average weight in the field from two randomly selected beds of fresh lettuce that were harvested and weighed. In total, an average of $1,702 \mathrm{~kg}$ was computed to be traded by farmers per year. Sale of this quantity yields revenue of $\mathrm{GH} \phi 6,066$ with marketing margin of $\mathrm{GH} \notin 3,630$ per year. 
3.3.2 Purchasing and Marketing Costs Analysis of Lettuce for Traders per Year

Table 7 presents the results on the analysis of traders' purchase and marketing of lettuce in the metropolis per year.

Table 7. Purchasing and marketing costs analysis of lettuce for traders per year

\begin{tabular}{|c|c|c|c|}
\hline Item & $M(S D)$ & Min & Max \\
\hline \multicolumn{4}{|l|}{ Wholesalers } \\
\hline Purchase trip per year & $96.00(0.00)$ & 96.00 & 96.00 \\
\hline Number of $15 \mathrm{~kg}$ bags bought & $672.00(198.74)$ & 384.0 & 960.00 \\
\hline Equivalent kg per year & $10080.00(2981.08)$ & 5760.0 & 14400.00 \\
\hline Unit cost per $15 \mathrm{~kg}$ bag $\mathrm{GH} \phi$ & $50.00(3.78)$ & 45.00 & 55.00 \\
\hline Unit sales per $15 \mathrm{~kg}$ bag $\mathrm{GH} \phi$ & $54.22(4.32)$ & 47.00 & 60.00 \\
\hline Revenue per year GHC & 36612.00 & & \\
\hline Cost of purchase GHc & 33540.00 & & \\
\hline \multicolumn{4}{|l|}{ Marketing costs per year GHф } \\
\hline Load and unloading & $1003.50(239.14)$ & 768.00 & 1500.00 \\
\hline Transportation & $1278.00(358.22)$ & 768.00 & 1920.00 \\
\hline Market toll & $108.00(33.94)$ & 96.00 & 192.00 \\
\hline Negotiation & $130.15(69.01)$ & 19.20 & 200.00 \\
\hline Communication & $129.40(74.81)$ & 19.20 & 250.00 \\
\hline Others & $144.00(67.88)$ & 48.00 & 192.00 \\
\hline Total marketing costs GHC & 2793.05 & & \\
\hline Total costs GHe & 36332.90 & & \\
\hline Marketing margin GHc & 3072 & & \\
\hline Profit margin GHe & 278.95 & & \\
\hline Margin per $15 \mathrm{~kg}$ bag GHC & 4.57 & & \\
\hline Margin per kilo GHc & 0.31 & & \\
\hline \multicolumn{4}{|l|}{ Retailers } \\
\hline Purchase trip per year & $96.00(0.00)$ & 96.00 & 96.00 \\
\hline Number of $15 \mathrm{~kg}$ bags & $123.00(42.82)$ & 96.00 & 192.00 \\
\hline Equivalent kg per year & $1845.00(642.31)$ & 1440.00 & 2880.00 \\
\hline Unit cost per $15 \mathrm{~kg}$ bag $\mathrm{GH} \phi$ & $61.06(4.11)$ & 55.00 & 70.00 \\
\hline Unit sales per $15 \mathrm{~kg}$ bag $\mathrm{GH} \varnothing$ & $72.63(2.53)$ & 69.00 & 79.00 \\
\hline Revenue per year GHC & 8886.00 & & \\
\hline Cost of purchase GHc & 7446.00 & & \\
\hline \multicolumn{4}{|l|}{ Marketing costs $G H \phi$} \\
\hline Load and unloading & $127.75(45.12)$ & 96.00 & 192.00 \\
\hline Transportation & $150.56(33.05)$ & 96.00 & 192.00 \\
\hline Market toll & $102.13(29.48)$ & 50.00 & 192.00 \\
\hline Negotiation & $74.18(39.29)$ & 4.80 & 144.00 \\
\hline Communication & $132.31(55.56)$ & 48.00 & 192.00 \\
\hline Others & $67.13(17.27)$ & 45.00 & 96.00 \\
\hline Total marketing costs GHc & 654.05 & & \\
\hline Total costs GHe & 8100.05 & & \\
\hline Marketing margin GHc & 1440.00 & & \\
\hline Profit margin GHc & 785.95 & & \\
\hline Margin per $15 \mathrm{~kg}$ bag GHC & 11.71 & & \\
\hline Margin per kilo GHc & 0.78 & & \\
\hline
\end{tabular}

Note. $M=$ mean; $(S D)=$ standard deviation, Min = minimum, Max = maximum.

1 US Dollar $(\$)=3.6$ Ghana New Cedi $(\mathrm{GH} \phi)$ in 2015 , Two (2) freshly harvested beds of lettuce $=15 \mathrm{~kg}$ on average.

Source: Author's computation from survey data, 2015. 
Revenue obtained from wholesalers' yearly transaction activities was GH $\notin 36,612$ with GH $\notin 33,540$ incurred as purchasing costs for an average quantity of 672 bags of lettuce, each weighing $15 \mathrm{~kg}$. Marketing margin was estimated at $\mathrm{GH} \notin 3,072$ with every kilogram of lettuce given a marketing margin of $\mathrm{GH} \phi 0.31$. Retailers' margin per kilogram of lettuce was estimated at GHф 0.78. A total of 123 bags were estimated to be marketed by retailers costing $\mathrm{GH} \phi 7,446$ and yields revenue of $\mathrm{GH} \phi 8,886$ from its sales resulting in a marketing margin of $\mathrm{GH} \notin 1,440$ for the total commodity traded per year.

3.3.3 Summary of Actors' Performance in Lettuce Investment in Peri-Urban Kumasi

Table 8 gives the summary of lettuce marketing margin distribution amongst actors in the metropolis.

Table 8. Summary of distribution of lettuce marketing margins amongst actors

\begin{tabular}{llll}
\hline Item & Producers & Wholesalers & Retailers \\
\hline Purchase prices GH $\phi$ & - & 33540.00 & 7446.00 \\
Production cost GH $\phi$ & 2436.44 & - & - \\
Marketing costs GHф & & & \\
Loading and unloading & - & 1003.50 & 127.75 \\
Transportation & - & 1278.00 & 150.56 \\
Market toll & - & 108.00 & 102.13 \\
Negotiation costs & 7.35 & 130.15 & 74.18 \\
Communication costs & 6.06 & 129.40 & 132.31 \\
Search costs & 31.71 & - & - \\
Other marketing cost & - & 144.00 & 67.13 \\
Total marketing costs & 45.12 & 2793.05 & 654.05 \\
Total costs GH $\phi$ & 2481.56 & 36332.90 & 8100.05 \\
Sales GH $\phi$ & 6066.26 & 36612.00 & 8886.00 \\
Marketing margin GH $\phi$ & $\mathbf{3 6 2 9 . 8 2}$ & $\mathbf{3 0 7 2 . 0 0}$ & $\mathbf{1 4 4 0 . 0 0}$ \\
\% share of margin & $\mathbf{4 4 . 6 0 \%}$ & $\mathbf{3 7 . 7 0 \%}$ & $\mathbf{1 7 . 7 0 \%}$ \\
Profit margin GH $\phi$ & 3584.70 & 278.95 & 785.95 \\
Percentage share of profit & $\mathbf{7 6 . 5 8}$ & $\mathbf{5 . 9 6}$ & $\mathbf{1 6 . 7 9}$ \\
Total kg traded & 1702.39 & 10080.00 & 1845.00 \\
Number of $15 \mathrm{~kg}$ bags & 113.49 & 672.00 & 123.00 \\
Margins/15 kg bag & 31.98 & 4.57 & 11.71 \\
Margin/kilo GH $\phi$ & 2.13 & 0.30 & 0.78 \\
Percentage margin/kilo & $\mathbf{6 6 . 0 0}$ & $\mathbf{9 . 3 5}$ & $\mathbf{2 4 . 3 2}$ \\
Returns on invest (\%) & $\mathbf{1 4 5 . 0 0}$ & $\mathbf{0 . 8 0}$ & $\mathbf{9 . 7 0}$ \\
\hline
\end{tabular}

Note. $M=$ mean; $(S D)=$ standard deviation, Min = minimum, Max = maximum.

1 US Dollar $(\$)=3.6$ Ghana New Cedi $(\mathrm{GH} \phi)$ in 2015 , Two (2) freshly harvested beds of lettuce $=15 \mathrm{~kg}$ on average.

Source: Author's computation from survey data, 2015.

The results indicate that in lettuce marketing, farmers benefit more than traders. It can be observed that traders incurred more marketing costs in getting the products to the markets unlike the farmers. Thus, this puts more pressure on the overall marketing margins obtained by traders. The marketing margin distribution for farmers, wholesalers and retailers were estimated at $\mathrm{GH} \varnothing 3,630(45 \%)$, $\mathrm{GH} \phi 3,072(38 \%)$ and $\mathrm{GH} \varnothing 1,440(18 \%)$ respectively. In terms of per kilo analysis of the marketing margin differences amongst actors, the results reveal that farmers get $\mathrm{GH} \phi 2.13(66 \%)$ for every kilogram of lettuce traded whilst wholesalers and retailers get $\mathrm{GH} \phi$ $0.3(9 \%)$ and $\mathrm{GH} \phi 0.78(24 \%)$ respectively for every kilogram lettuce traded. Moreover, results from the returns on investment analysis for the respective agents show that farmers get GH 1.45 while wholesalers and retailers get GH $\not 0.008$ and GH $\varnothing 0.097$ for every Ghana cedi invested in lettuce per year respectively. Lettuce production and marketing in the metropolis yields more returns to farmers compared to traders, and it is economically preferred to spring onions by farmers. The returns on investment for farmers is about $145 \%$ indicating that farmers get $\mathrm{GH} \phi 1.45$ for every Ghana cedi they invest in lettuce per year, while wholesalers and retailers only 
get $1 \%$ and $10 \%$ respectively for every Ghana cedi they invest in lettuce per year. These percentages represent 1 and 10 pesewas for every Ghana cedi invested by traders.

\subsection{Performance Assessment of Actors in Cabbage Investment in Peri-Urban Kumasi}

3.4.1 Production and Marketing Costs Analysis of Cabbage for Farmers per Year

Table 9 presents the details on the analysis of the production and marketing costs for cabbage farmers in Kumasi metropolis.

Table 9. Production and marketing costs analysis of cabbage for farmers per year

\begin{tabular}{|c|c|c|c|}
\hline Item & $M(S D)$ & Min & Max \\
\hline Land preparation $\mathrm{GH} \varnothing$ & $291.08(159.87)$ & 58.31 & 680.32 \\
\hline Sowing GH $\varnothing$ & $147.69(96.68)$ & 27.77 & 399.86 \\
\hline Weeding GHф & $265.46(258.13)$ & 27.77 & 666.43 \\
\hline Fertilizer application $\mathrm{GH} \varnothing$ & $87.05(54.71)$ & 27.77 & 183.27 \\
\hline Manure application $\mathrm{GH} \varnothing$ & $94.02(57.08)$ & 27.77 & 208.26 \\
\hline Cost of seed GH $\varnothing$ & $253.02(158.05)$ & 48.59 & 721.97 \\
\hline Cost of manure $\mathrm{GH} \phi$ & $70.79(56.29)$ & 10.41 & 222.14 \\
\hline Cost of Attack GHф & $43.50(29.06)$ & 13.88 & 83.30 \\
\hline Cost of Golan $\mathrm{GH} \phi$ & $41.65(27.77)$ & 27.77 & 83.30 \\
\hline Cost of Consider GH $\varnothing$ & $67.26(48.85)$ & 8.33 & 173.55 \\
\hline Cost of Dytrin GHф & $75.15(41.96)$ & 13.88 & 138.84 \\
\hline Cost of Cobos GHф & $38.76(31.24)$ & 13.88 & 83.30 \\
\hline Cost of Emma GHф & $45.95(11.91)$ & 34.71 & 62.48 \\
\hline Cost of Melton $\mathrm{GH} \phi$ & $112.81(33.34)$ & 62.48 & 138.84 \\
\hline Depreciated fixed cost $\mathrm{GH} \varnothing$ & $14.80(14.49)$ & 1.09 & 69.14 \\
\hline Average total production costs & 1648.98 & & \\
\hline \multicolumn{4}{|l|}{ Marketing costs $G H \phi$} \\
\hline Searching costs & $16.75(12.79)$ & 1.39 & 69.42 \\
\hline Communication costs & $3.19(2.84)$ & 0.17 & 16.66 \\
\hline Negotiation costs & $3.88(2.50)$ & 0.69 & 11.11 \\
\hline Average total marketing costs & 23.83 & & \\
\hline Total costs GHC & 1672.81 & & \\
\hline \multicolumn{4}{|l|}{ Revenue analysis } \\
\hline Number of bags produced & $44.69(40.09)$ & 5.57 & 222.96 \\
\hline Total kg sold & $6703.08(6013.87)$ & 836.10 & 33444.1 \\
\hline Cost per $150 \mathrm{~kg}$ bag & $66.15(7.79)$ & 55.00 & 90.00 \\
\hline Revenue per year GHC & 2985.20 & & \\
\hline Marketing margin GHC & 1336.22 & & \\
\hline Profit margin GHc & 1312.39 & & \\
\hline Margin per $150 \mathrm{~kg}$ bag GHc & 29.9 & & \\
\hline Margin per kilo GHæ & 0.19 & & \\
\hline
\end{tabular}

Note. $M=$ mean; $(S D)=$ standard deviation, Min = minimum, Max = maximum.

1 US Dollar $(\$)=3.6$ Ghana New Cedi $(\mathrm{GH} \phi)$ in 2015, 1 Maxi bag of cabbage $=150 \mathrm{~kg}$.

Source: Author's computation from survey data, 2015.

A total production cost of $\mathrm{GH} \phi 1,649$ was incurred in the production of 45 bags of cabbage each weighing 150 $\mathrm{kg}$, as was estimated from the Abinchie market after weighing two maxi bags of cabbage. This same weight is consistent with the finding of $\mathrm{Zu}$, Wongnaa, and Appiah (2014). A total of 6,703 $\mathrm{kg}$ of cabbage was traded per year by farmers in the metropolis. Sales analysis of this quantity reveals a revenue of GH $\notin 2,985$ per year. The overall marketing margin for this quantity was estimated at $\mathrm{GH} \phi 1,336$ per year. 


\subsubsection{Purchasing and Marketing Costs Analysis of Cabbage for Traders per Year}

Table 10 shows the various transaction activities undertaken by traders per year in the purchasing and marketing of cabbage in the metropolis.

Table 10. Purchasing and marketing cost analysis of cabbage for traders per year

\begin{tabular}{|c|c|c|c|}
\hline Item & $M(S D)$ & Min & Max \\
\hline \multicolumn{4}{|l|}{ Wholesalers } \\
\hline Purchase trip per year & $96.00(0.00)$ & 96.00 & 96.00 \\
\hline Number of $150 \mathrm{~kg}$ bags & $992.00(381.71)$ & 480.00 & 1920.00 \\
\hline Equivalent kg per year & $148800.00(57256.12)$ & 72000.00 & 288000.00 \\
\hline Unit cost per bag GH $\varnothing$ & $94.00(19.93)$ & 50.00 & 130.00 \\
\hline Unit sales per bag $\mathrm{GH} \varnothing$ & $112.33(16.02)$ & 80.00 & 140.00 \\
\hline Revenue per year GHe & 110048.00 & & \\
\hline Cost of purchase GHC & 92672.00 & & \\
\hline \multicolumn{4}{|l|}{ Marketing costs $G H \phi$} \\
\hline Load and unloading & $2752.00(1314.12)$ & 1152.00 & 5760.00 \\
\hline Transportation & $5260.80(2230.60)$ & 2880.00 & 11520.00 \\
\hline Market toll & $171.43(85.69)$ & 96.00 & 384.00 \\
\hline Negotiation & $233.60(208.74)$ & 19.20 & 960.00 \\
\hline Communication & $317.16(267.15)$ & 19.20 & 960.00 \\
\hline Others & $268.80(97.36)$ & 96.00 & 384.00 \\
\hline Total marketing costs GHd & 9003.78 & & \\
\hline Total costs GHe & 101675.78 & & \\
\hline Marketing margin GHd & 17376.00 & & \\
\hline Profit margin GHe & 8372.22 & & \\
\hline Margin per $150 \mathrm{~kg}$ bag GHd & 17.52 & & \\
\hline Margin per kilo GHc & 0.12 & & \\
\hline \multicolumn{4}{|l|}{ Retailers } \\
\hline Purchase trip per year & $96.00(0.00)$ & 96.00 & 96.00 \\
\hline Number of $150 \mathrm{~kg}$ bags & $146.82(87.59)$ & 48.00 & 480.00 \\
\hline Equivalent kg per year & $22023.53(13138.31)$ & 7200.00 & 72000.00 \\
\hline Unit cost per bag GH $\varnothing$ & $101.77(19.68)$ & 50.00 & 120.00 \\
\hline Unit sales per bag $\mathrm{GH} \phi$ & $144.56(20.01)$ & 100.00 & 180.00 \\
\hline Revenue per year GHc & 20858.82 & & \\
\hline Cost of purchase GHe & 14589.18 & & \\
\hline \multicolumn{4}{|l|}{ Marketing costs $G H \phi$} \\
\hline Load and unloading & $237.09(146.45)$ & 48.00 & 672.00 \\
\hline Transportation & $264.00(164.03)$ & 96.00 & 672.00 \\
\hline Market toll & $122.79(55.45)$ & 24.00 & 192.00 \\
\hline Negotiation & 107.05(96.39) & 4.80 & 576.00 \\
\hline Communication & $273.16(379.13)$ & 48.00 & 1920.00 \\
\hline Others & $96.00(0.00)$ & 96.00 & 96.00 \\
\hline Total marketing costs GHC & 1100.09 & & \\
\hline Total costs GHC & 15689.27 & & \\
\hline Marketing margin GHd & 6269.65 & & \\
\hline Profit margin GHe & 5169.55 & & \\
\hline Margin per $150 \mathrm{~kg}$ bag GHd & 42.71 & & \\
\hline Margin per kilo GHc & 0.29 & & \\
\hline
\end{tabular}

Note. $M=$ mean; $(S D)=$ standard deviation, Min = minimum, Max = maximum.

1 US Dollar $(\$)=3.6$ Ghana New Cedi $(\mathrm{GH} \phi)$ in 2015,1 Maxi bag of cabbage $=150 \mathrm{~kg}$.

Source: Author's computation from survey data, 2015. 
It can be seen from Table 10 that wholesalers incurred on the average a total purchasing cost of GH $\phi 92,672$ for 992 bags of cabbage, each weighing $150 \mathrm{~kg}$. This number of bags is equivalent to $148,800 \mathrm{~kg}$ of cabbage traded by wholesalers per year. Estimated revenue obtained from the sale of this quantity at an average price of $\mathrm{GH} \phi$ 112 per bag yields a revenue of $\mathrm{GH} \phi 110,048$ enabling a marketing margin of $\mathrm{GH} \phi 17,376$ to wholesalers per year. The results further show that per kilogram transaction of cabbage by wholesalers yields a marketing margin of GHф 0.12 per year. Moreover, it was found that for retailers, 147 bags of cabbages were marketed with an incurred purchasing cost of GH $\phi 14,589$ per year. Sale of this quantity by retailers earned them revenue of GH $\phi$ 20,859 with resulting marketing margins of $\mathrm{GH} \phi 6,270$ per year.

\subsubsection{Summary of Actors' Performance in Cabbage Investment in Peri-Urban Kumasi}

A summary of the distribution of marketing margins amongst actors for cabbage production and marketing in the metropolis of Kumasi is presented in Table 11.

Table 11. Summary of distribution of cabbage marketing margin amongst actors

\begin{tabular}{|c|c|c|c|}
\hline Item & Producers & Wholesalers & Retailers \\
\hline Purchase prices $\mathrm{GH} \phi$ & - & 92672.00 & 14589.18 \\
\hline Production cost $\mathrm{GH} \phi$ & 1648.98 & - & - \\
\hline \multicolumn{4}{|l|}{ Marketing costs $G H \phi$} \\
\hline Loading and unloading & - & 2752.00 & 237.09 \\
\hline Transportation & - & 5260.80 & 264.00 \\
\hline Market toll & - & 171.43 & 122.79 \\
\hline Negotiation costs & 3.88 & 233.60 & 107.05 \\
\hline Communication costs & 3.20 & 317.16 & 273.16 \\
\hline Search costs & 16.75 & - & - \\
\hline Other marketing cost & - & 268.80 & 96.00 \\
\hline Total marketing costs $\mathrm{GH} \varnothing$ & 23.84 & 9003.78 & 1100.10 \\
\hline Total costs $\mathrm{GH} \varnothing$ & 1672.81 & 101675.80 & 15689.27 \\
\hline Sales GHф & 2985.20 & 110048.00 & 20858.83 \\
\hline Marketing margin $\mathrm{GH} \phi$ & 1336.22 & 17376.00 & 6269.65 \\
\hline$\%$ share of margin & 5.35 & 69.55 & 25.10 \\
\hline Profit margin GHф & 1312.39 & 8372.22 & 5169.55 \\
\hline$\%$ share of profit & 8.84 & 56.36 & 34.80 \\
\hline Total kg traded & 6703.08 & 148800.00 & 22023.53 \\
\hline Number of $150 \mathrm{~kg}$ bags & 44.69 & 992.00 & 146.82 \\
\hline Margins/150 kg bag GHф & 29.9 & 8.44 & 42.71 \\
\hline Margin/kg cabbage $\mathrm{GH} \varnothing$ & 0.19 & 0.06 & 0.29 \\
\hline$\%$ margin/kilo & 36.85 & 10.37 & 52.80 \\
\hline Returns on invest. (\%) & 78.50 & 8.23 & 33.10 \\
\hline
\end{tabular}

Note. $M=$ mean; $(S D)=$ standard deviation, Min = minimum, Max $=$ maximum.

1 US Dollar $(\$)=3.6$ Ghana New Cedi $(\mathrm{GH} \phi)$ in 2015,1 Maxi bag of cabbage $=150 \mathrm{~kg}$.

Source: Author's computation from field survey, 2015.

It was observed that out of the total marketing margins accrued by actors for cabbage marketing, $70 \%$ goes to wholesalers while $25 \%$ goes to retailers with farmers having only $5 \%$. This finding concurs to that of Godfrey and Mwakaje (2012) who discovered that about $31 \%$ of the total gross margin for potato marketing in Rugwe district in Tanzania is enjoyed by wholesalers while only $8 \%$ goes to farmers. The result further reveals that on a per kilogram basis, retailers had more margin per kilo of cabbage traded (GHф 0.29) followed by farmers (GH $\phi$ 0.19). Moreover, It can be observed that farmers had more returns on investment of $79 \%$ relative to $33 \%$ of retailers' implying that for every Ghana cedi invested in cabbage, farmers get GH $\not 0.79$ followed by retailers $\mathrm{GH} \phi$ 0.33. In comparing the returns on investment accrued by retailers for vegetables in this study with that of the returns on capital employed for retailers in a study by Haruna et al. (2012) and Alcos, Supangco, and Revilleza, 
(2001) for tomatoes in both Ghana and Philippines, tomatoes were observed to yield more returns compared to spring onions, lettuce and cabbage.

\section{Conclusions and Recommendations}

The findings of the study show that with the exception of lettuce, traders had more marketing margins than farmers for onions and cabbage. The returns on investment analysis revealed that farmers are far better off in terms of efficiency in the respective operations of the various enterprises. The study identifies information flow gap on existing market prices of these products to farmers. Hence, such condition is a major cause of farmers' accusation of being cheated in the margins, particularly when regulatory measures against products gluts and price stability are being enforced by traders' cartel in the bid to reduce risk of incurring losses and excess damage to products due to inadequate and ineffective storage facilities for perishables like vegetables. Thus, farmers' claim of being cheated in the marketing margins of vegetables especially spring onions, lettuce and cabbage within the metropolis has been holistically proven to be untenable by this study. This current study further shows that farmers' performance in the investment of these three leafy vegetables is better compared to traders based on the return on investments. The overall huge margin obtained by traders was observed to be caused by the huge capital they operate with which allows them to buy more goods at a time and therefore stand the chance of acquiring more margin. This does not however give an indication of better performance by such actors. The study therefore recommends that policy consideration be made in the improvement of information flow amongst all actors along the marketing channels of vegetables in the country via convenient means such as farmer associations and weekly radio broadcast on market prices of products. This will enhance and enable a fair podium devoid of scepticism, guile and opportunism in the marketing system of vegetables for the benefit of all stakeholders. Furthermore, maintaining the stride in the attainment of food security is very imperative and therefore sustaining farmers' motivation in the production process remains critical. Thus farmers should be sensitized on their unawareness on margin distributions and returns on their investments, which has resulted in the assumed notion of being cheated in the margins and embrace their perpetual effort in the struggle for food security in the country.

\section{Acknowledgements}

Special thanks and appreciation go to the West Africa Agricultural Productivity Programme Sierra Leone (WAAPP/SL) through the Sierra Leone Agricultural Research Institute (SLARI) for the financial support given this work. Special thanks go to Dr. Fred Nimoh, Dr. Robert Aidoo, Dr. Kwasi Ohene-Yankyera, Dr. Gyiele-Nurah, Dr. Dadson Awunyo-Vitor and Prof. S. C. Fialor, all of the Department of Agricultural Economics Agribusiness and Extension of the Kwame Nkrumah University of Science and Technology (KNUST) in Kumasi Ghana for their constructive comments and critique. Moreover, special appreciation goes to Stanley Boakye-Acheampong and Prosper Wie of the same department for their assistance in data collection during the survey.

\section{References}

Adugna, G. T. (2009). Analysis of fruit and vegetable market chains in Alamata, southern zone of Tigray: The case of onion, tomato and papaya.

Alcos, J., Supangco, E., \& Revilleza, J. (2001). Marketing Efficiency Study on Tomato in Barangay Taguibo, Mati, Davao Oriental. Republic of Philippine, Department of Agriculture.

Amoah, T. S., Debrah, A. I., \& Razak, A. R. (2014). Technical Efficiency of Vegetable Farmers in Peri-Urban Ghana Influence and Effects of Resource Inequalities. American Journal of Agriculture and Forestry, 2(3), 79-87. http://dx.doi.org/10.11648/j.ajaf.20140203.14

Baba, S. H., Zargar, B. A., Ganaie, S. A., Yousuf, S., \& Sehr, H. (2010). Gender Participation in Vegetable Cultivation in Kashmir Valley. Indian Res. J. Ext. Edu., 10(2), 66-69. Retrieved from http://seea.org.in/vol10-2-2010/14.pdf

Bakari, U. M., \& Usman, J. (2013). Marketing of Some Selected Vegetables: In Yola-North and South Local Government Areas of Adamawa State, Nigeria. The International Journal of Engineering and Science, 2(11), 13-17.

Blake, B., \& Kasanga, K. (1997). Kumasi Natural Resource Management Research project. Inception report; NRI, Natural Resource Institute, The University of Greenwich, UK and University of Science and Technology, Kumasi, Ghana. 
Cornish, G. A., \& Lawrence, P. (2001). Informal irrigation in peri-urban areas: A summary of findings and recommendations. DFID's Water KAR Project R7132, Report OD 144 (p. 54). Wallingford, UK: HR Wallingford.

Cornish, G. A., Aidoo, J. B., \& Ayamba, I. (2001). Informal irrigation in the peri-urban zone of Kumasi, Ghana. An analysis of farmer activity and productivity. DFID's Water KAR Project R7132, Report OD/TN 103 (p. 39). Wallingford, UK: HR Wallingford.

Drechsel, P., \& Keraita, B. (Eds.). (2014). Irrigated urban vegetable production in Ghana: Characteristics, benefits and risk mitigation (2nd ed., p. 247). Colombo, Sri Lanka: International Water Management Institute (IWMI). http://dx.doi.org/10.5337/2014.219

FAO (Food and Agricultural Organisation). (2015). FAO and the 17 sustainable development goals, sustainable development knowledge platform. Retrieved from http://sustainabledevelopment.un.org

FAO (Food and Agriculture Organization). (2006). Value Chain Analysis: A Case Study on Mangoes in Kenya, Prepared By the Sugar and Beverages Groups Raw Materials. Tropical and Horticultural Products Service Commodities and Trade Divisions Food and Agriculture Organization of the United States.

Food Outlook. (2012). A global market analysis. FAO Food Outlook November 2012 - Food and Agriculture Organization. Retrieved from http://www.fao.org/docrep/016/a1993e/al993e00.pdf

Ghana Statistical Service (GSS). (2012). 2010 Population and Housing census summary report of final results. A publication of the Ghana Statistical Service, Accra.

Godfrey, N., \& Mwakaje, E. G. (2012). Analysis of Round Potato Marketing in Tanzania: The Case of Rungwe District, Tanzania. International Journal of Business and Social Science, 3(23).

Haruna, I., Nkegbe, P. W., \& Ustarz, Y. (2012). Structure, conduct and performance of tomato marketing in Ghana. Journal of Economics and Sustainable Development, 3(10).

Hoornweg, D., \& Munro-Faure, P. (2008). Urban Agriculture for Sustainable Poverty Alleviation and Food Security. Retrieved from http://www.fao.org/fileadmin/templates/FCIT/.../UPA_-WBpaper-Final_October_ 2008.pdf

Kohls, R., \& Uhl, N. (1985). Marketing of agricultural products (6th ed.). McMillian Publishing Company, NewYork, USA. Retrieved from https://ideas.repec.org/a/eee/agisys/v21y1986i4p313-315.html

Lumpkin, T. A., Weinberger, K., \& Moore, S. (2005). Increasing Income through Fruits and Vegetable Production: Opportunities and Challenges (p. 10). Marrakech, Morocco. Retrieved from https://library.cgiar.org/bitstream/handle/10947/.../agm05_stake_4c_lumpkin.pdf

Maxwell, D. (1999). The political economy of urban food security in sub-Saharan Africa. World Development, 27(11), 1939-1953. http://dx.doi.org/10.1016/S0305-750X(99)00101-1

Mou, H. N. (2012). Profitability of flower production and marketing system of Bangladesh. Bangladesh J. Agril. Res., 37(1), 77-95. http://dx.doi.org/10.3329/bjar.v37i1.11179

Obuobie, E., Danso, G., \& Drechsel, P. (2003). Access to land and water for urban vegetable farming in Accra. Urban Agriculture Magazine, 11, 15-17.

Obuobie, E., Keraita, B., Danso, G., Amoah, P., Cofie, O. O., Raschid-Sally, L., \& Drechsel, P. (2006). Irrigated urban vegetable production in Ghana: Characteristics, benefits and risks (p. 150). IWMI-RUAF-CPWF, Accra, Ghana: International Water Management Institute (IWMI).

Ortiz, N. C. M., Campbell, C., \& Hyman, B. (2010). Analyzing Market Reforms and Food Distribution Systems in Accra, Ghana, Lessons and Implications for Reforming the Bazurto Market of Cartagena, Colombia. Massachusetts Institute of Technology Department of Urban Studies and Planning Case Study. Retrieved from http://colabradio.mit.edu/wp-content/uploads/2010/02/CasodeEstudio_Ghana.pdf

Owusu, V., \& Owusu, A. M. (2010). Measuring Market Potential for Fresh Organic Fruit and Vegetable in Ghana. Contributed Paper presented at the Joint 3rd African Association of Agricultural Economists (AAAE) and 48th Agricultural Economists Association of South Africa (AEASA) Conference, Cape Town, South Africa, September 19-23, 2010. Retrieved from http://purl.umn.edu/95955

Randela, R. (2005). Integration of emerging cotton farmers into the commercial Agricultural economy (Unpublished $\mathrm{PhD}$ thesis). University of the Free State, Bloemfontein. 
UNDP (United Nations Development Programme). (1996). Urban agriculture: food, jobs and sustainable cities. UN Development Program. Publication Series for Habitat II (Vol. 1). New York, USA: UNDP. Retrieved from http://www.cityfarmer.org/smitbook $90 . h t m l$

Woldesenbet, T. A. (2013). Value chain analysis of vegetables: The case of habro and kombolcha woredas in Oromia region, Ethiopia. A Thesis Submitted to School of Agricultural Economics and Agribusiness, School of Graduate Studies.

Zu, K. S. A., Wongnaa, C., \& Appiah, F. (2014). Vegetable Handling, Distribution, and Wholesale Profitability in“Abinchi” Night Market, Kumasi-Ghana. Journal of Post-Harvest Technology. Retrieved October 12, 2016, from http://jpht.info/index.php/jpht/article/view/17435/9167

\section{Copyrights}

Copyright for this article is retained by the author(s), with first publication rights granted to the journal.

This is an open-access article distributed under the terms and conditions of the Creative Commons Attribution license (http://creativecommons.org/licenses/by/4.0/). 